\title{
Bilgisayar ve Öğretim Teknolojileri Eğitimi Öğretmen Adaylarının Bilişim Güvenliği Bilgilerinin Çeşitli Değişkenlere Göre İncelenmesi ${ }^{*}$
}

\section{Ömer Faruk GÖKMEN ${ }^{\mathrm{a}^{* *}}$, Özcan Erkan AKGÜN ${ }^{\mathrm{a}}$}

${ }^{a}$ Sakarya Üniversitesi, Eğitim Fakültesi, Sakarya/Türkiye

Makale Bilgisi

DOI: $10.14812 /$ cufej.2015.004

Makale Geçmişi:

Geliş 25 Aralık 2014

Düzeltme 11 Ocak 2015

Kabul $\quad 02$ Mart 2015

Anahtar Kelimeler:

Bilişim güvenliği,

Bilişim güvenliği bilgisi,

BÖTE

Öğretmen adayı
Öz

Bu çalışmanın amacı, Bilgisayar ve Öğretim Teknolojileri Eğitimi (BÖTE) öğretmen adaylarının bilişim güvenliği bilgilerin ne düzeyde olduğunun tespit edilmesidir. Çalışma tarama modeli ile yürütülmüştür. Araştırmanın çalışma grubunu; Sakarya, Amasya, Erzincan ve Siirt üniversitelerinin BÖTE bölümünde okuyan üçüncü ve dördüncü sınıf öğretmen adayları oluşturmaktadır. Araştırma verileri, "Bilişim Güvenliği Bilgisi” anketi ile elde edilmiştir. Verilerin analizinde yüzde, frekans değerlerinden yararlanılırken, adayların bilişim güvenliği bilgilerinin çeşitli değişkenlere göre anlamlı farklılıklar gösterip göstermediğini belirlemek için ise Kruskal Wallis H-Testi ve Mann Whitney UTesti kullanılmıştır. Araştırma sonuçlarına göre BÖTE öğretmen adayların bilişim güvenliği bilgilerinin düşük düzeyde olduğu tespit edilmiştir. Ayrıca BÖTE öğretmen adayların bilişim güvenliği bilgilerinin cinsiyete ve öğrenim görülen üniversiteye göre farklılaştığı görülürken; yaşa, sınıfa, bilgisayara sahip olma yılına, günlük bilgisayar kullanım süresine, günlük internet kullanım süresine ve bilişim güvenliğin yönelik bir ders veya kurs alıp almama durumuna göre farklılık göstermediği tespit edilmiştir. Araştırma sonuçlarından yola çıkarak, BÖTE bölümünün öğretim programında bilişim güvenliği dersinin yer almasının faydalı olacağı sonucuna ulaşılmıştır.

\section{An Analysis of Computer Education and Instructional Technology Student Teachers' Knowledge of Information Security according to Several Variables}

\begin{tabular}{l} 
Article Info \\
\hline DOI: 10.14812/cufej.2015.004 \\
\hline Article history: \\
Received $\quad 25$ December 2014 \\
Revised $\quad 11$ January 2015 \\
Accepted $\quad 02$ March 2015 \\
\hline Keywords: \\
Information security, \\
Information security knowledge, \\
CEIT, \\
Student teachers.
\end{tabular}

\begin{abstract}
The purpose of this study is to identify the knowledge of CEIT student teachers on the information security. The study was conducted via survey method and profited from the third and fourth grade 375 CEIT student teachers at universities in Sakarya, Amasya, Erzincan and Siirt. The data was collected with the means of Information Security Knowledge Instrument. In the analyzing the data, frequency and percentage analyses were employed, and in determining whether the student teachers' knowledge of information security differs according to the various variables, Mann Whitney $U$ test and Kruskall Wallis tests were applied. According to the results, it was identified that CEIT student teachers' knowledge level of information security is low. In addition, it was concluded that while CEIT student teachers' knowledge of information security differs according to gender and university, it doesn't change with learners' age, grade, period of computer ownership, daily computer and internet usage time, and taking any lecture on information security. Based on the results, it will be useful for student teachers' to go through a compulsory course in CEIT curriculum for the aim of receiving knowledge in information security.
\end{abstract}

\footnotetext{
* Bu çalışma ikinci yazar danışmanlığında birinci yazar tarafından hazırlanan "Bilgisayar ve Öğretim Teknolojileri Eğitimi Öğretmen Adaylarının Bilişim Güvenliği Eğitimi Verebilme Yeterliliği”” adlı tez çalışmasından faydalanılarak oluşturulmuştur.

Yazar: omerfarukgokmenn@gmail.com
} 


\section{Giriş}

20. yüzyılın son dönemlerinden itibaren sosyal, ekonomik ve toplumsal yaşamda önemli değişikler yaşanmıştır. Bu değişiklikler neticesinde insanlık, sırasıyla tarım toplumundan sanayi toplumuna son olarak da bilgi toplumu denilen bulunduğumuz zamana geçmiştir (Şahin, Çetin \& Yıldırım, 2009). Bilgi toplumuna geçiş süreci, bilişim teknolojilerinde yaşanan gelişmelerle hızlanmıştır. Son dönemlerde bilişim teknolojilerinin evlerde, eğitimde, devlet hizmetlerinde, sağlık hizmetlerinde, ticarette vb. daha birçok alanda kullanımının yaygınlaşmasıyla (Çelik, 2007) bu süreç daha da hızlanmaktadır. Bireyler ve kurumlar bilişim teknolojileri ve internet kullanımının yaygınlaşmasıyla kolay ve çift yönlü iletişim kurma, bilgiye ulaşma, bilgi edinme, bilgi aktarma, gelişmeleri takip etme ve daha birçok imkâna kavuşmuştur. Web siteleri, bloglar, forumlar, elektronik posta, haber grupları, sohbet odaları, video konferanslar arama motorları bireylerin bilgi edinme ve paylaşma konusunda yoğun olarak faydalandıkları uygulamalardır (Taş \& Kestellioğlu, 2011). Türkiye İstatistik Kurumu'nun (TUiK) 2013 yılında yayınladığı istatistikler incelendiğinde her geçen yıl bilgisayar ve internet kullanımının arttığı görülmektedir (TUiK, 2013). TUiK istatistiklerinde 2013 yılında kamuda, işletmelerde vb. gibi alanlarda bilgisayar kullanımı \%92 iken evlerde bu oranın \%50 olduğu görülmektedir. Internet kullanımına bakıldığında ise kamuda, işletmelerde vb. alanlarda \%91 iken evlerde \% 49 olduğu görülmektedir. Ayrıca Internet World Stats (2012) istatistiklerine göre ülkemiz Avrupa genelinde 2012 itibariyle internet kullanımında beşinci sırada yer almaktadır.

Bilişim teknolojilerinin ve internetin sağladığı özellikler yaşamın elektronik ortama taşınmasını ve e'li yaşama geçişi sağlamıştır. Elektronik ortama geçiş ile devlet, eğitim, ticaret, sağlık vb. kurumlar köklü değişiklikler geçirerek yeni yapılara dönüşmektedirler. Özellikle son dönemlerde e-devlet, e-ticaret, ebelediye, e-öğrenme gibi kavramlar sıklıkla duyulmakta ve bu gibi hizmetlerin kullanımı hızlı bir şekilde artmaktadır (Dedeoğlu, 2006). Günümüzde ticari faaliyetlerin internet üzerinden gerçekleşmesinde bir artış olduğu muhakkaktır. Özellikle e-ticaretin geniş ürün yelpazesi, maliyet düşüklüğü, taleplere hızlı cevap verme eşit erişim tanıma gibi imkânlar sağlaması bu artışın hızını daha da artıran önemli etmenler olarak görülmektedir (Aydın \& Sarısakal, 2003). Benzer şekilde e-devlet hizmetlerinin devlet kurumlarındaki yoğunluğu azaltması, gerekli işlemlerin internet üzerinden yapılmasını sağlaması, bireylere zaman bakımından kazanç sağlaması vb. daha birçok fırsatı sunması bu hizmetin kullanımını artırmaktadır (Türkiye Bilişim Şurası (TBŞ), 2002). Bilişim teknolojileri ve internetin ticaret ve devlet faaliyetlerinde kullanımının yaygınlaşması eğitim-öğretim faaliyetlerini de etkilemiştir. Bilgisayar destekli eğitim, internet destekli eğitim, uzaktan eğitim gibi kavramlar bilişim teknolojileri ve internet kullanımının artmasıyla sıklıkla duyulmaktadır. Bu açıdan bakıldığında bilişim teknolojileri ve internetin toplum hayatında, ticarette, kamu kurum/kuruluşlarında, eğitimde vb. daha birçok alanda önemli faydalarının olduğu görülmektedir (Taş \& Kestellioğlu, 2011). Fakat elektronik ortamda bulunan bilginin veya verinin kötü niyetli kişiler tarafından ele geçirilerek bireylere veya kurum/kuruluşlara büyük zararları da olabilmektedir. Son yıllarda bilgisayar ve internet ortamında güvenliği tehdit eden kullanıcı veya yazılım tabanlı unsurlar artmakta ve bu güvenliği tehdit eden unsurlar bilişim sistemlerine ciddi zararlar vermektedir.

ABD'de 2009 yılında Bilgisayar ve Güvenlik Enstitüsü'nün (Computer Security Enstitute) gerçekleştirdiği bilgisayar suçları ve güvenlik araştırmasında kötücül yazılım bulaşması, robot virüsler (botlar), oltalama (phishing), dolandırıcılık, hizmet dışı atakları (Denial of Service), web sitesi tahrifatı, dizüstü veya mobil cihazların çalınması veya kaybolması, şifre koklama (password sniffing) en çok gerçekleşen saldırılar olarak tespit edilmiştir (Richardson, 2009). Dünya genelinde araştırma yapan Symantec (2013), günümüzde kullanımı artan Android işletim sistemine sahip mobil telefonlara yönelik saldırıların da her geçen gün arttığını belirtmektedir. Günden güne artan oltalama saldırıları ise, en çok finans organizasyonlarını ve bilgi servislerini hedef almaktadır. E-mail yoluyla oltalama saldırıları sırasıyla en çok devlet ve kamu kurumlarında, finans kuruluşlarında ve eğitim sektöründe tespit edilmiştir. Symantec'in her yıl gerçekleştirdiği araştırma sonuçları, her geçen gün tehdit sayısının ve çeşidinin arttığını göstermektedir. Marinos (2013) araştırmasında kritik altyapılar, mobil bilişim, sosyal ağlar, bulut bilişim gibi alanlara yönelik saldırıların arttığını tespit etmiştir. Bu saldırılar en fazla; internetten kasıtlı 
veya kasıtsız indirilen programlar, zararlı yazııımlar, kod enjekte etme, hizmet dışı atakları, oltalama, spam, veri ihlali, kimlik hırsızlı̆ı, fiziksel zarar, bilgi sızdırma şeklinde gerçekleştirilmektedir. Bunlara ek olarak mobil teknolojilere yönelik tehditlerin de arttığı görülmektedir.

Ülkemizde yapılan araştırmalar ve çalışmalar incelendiğinde, Kaçakçılık ve Organize Suçlarla Mücadele (KOM) Daire Başkanlığı tarafından hazırlanan ve 2011 yılında yayınlanan rapora göre bilişim suçlarına yönelik toplam 3901 olay gerçekleşmiş ve 4157 şüpheli şahıs hakkında işlem yapılmışır. En fazla işlenen bilişim suçları; banka ve kredi kartı dolandııııı̆̆ı̆, bilişim sistemlerine karşı işlenen suçlar, internet bankacılığı dolandırıcılığı, internet aracılığıyla nitelikli dolandıııılıktır. Bunları sırasıyla telif hakları, müstehcenlik, çocuk istismarı suçları takip etmektedir (KOM, 2011). Canbek (2005) genel olarak gerçekleştirilen saldırıların; virüs, solucan, truva atı gibi zararlı yazııımlar, arka kapılar (back door), casus yazılım (spyware), uzaktan yönetim araçları, robot virüsler, saldırgan ActiveX kodları, sistem aracı gibi gözüken virüsler (rootkitler), e-posta bombardımanı, veri trafiğini izleme (sniffing), veri trafiğini izlerken gizlenme (spoofing), web formlarına zararlı sql kodları enjekte etme, oltalama ve reklam bedelli yazılım (adware) gibi unsurlarla gerçekleştiğini belirtmiştir.

Türkiye'de yapılan internet güvenliği araştırmasına göre sektörlere yönelik gerçekleştirilen saldırılar arasında risk oranı en fazla olan üçüncü sektörün eğitim sektörü olduğu tespit edilmiştir (Koç.net, 2005). Symantec (2103) tarafından gerçekleştirilen araştırma sonuçlarına göre ise, saldırıların sırasıyla en çok devlet ve kamu kurumlarına, finans kuruluşlarına ve eğitim sektörüne yönelik yapıılığı tespit edilmiştir. Yapılan bu araştırmalar neticesinde; bireylerin bilgisayar ve internet ortamında güvenli hareket etmelerini, gerekli önlemleri almalarını sağlamak ve bireyleri güvenlik konusunda bilgilendirmek için çeşitli çalışmalar gerçekleştirilmektedir. Bu anlamda ülkemizde bilinçlendirme çalışmaları kapsamında web siteleri (Bilgimi Koruyorum, 2011; Ulusal Bilgi Güvenliği Kapısı, 2014) oluşturulmakta, konferanslar düzenlenmekte (Siber Güvenlik Konferansı, 2014) ve projeler (Güvenli ve Bilinçli İnternet Kullanım Projesi, 2013) yürütülmektedir. Bunların yanında kullanıcıların internet ortamında kumar oynama, sağlık için tehlikeli madde temini, sakıncalı içerikler gibi durumlarla karşılaşıldı̆̆ında ihbar edebilecekleri ihbar merkezi kurulmuştur (Telekomünikasyon iletişim Başkanlığı Internet İhbar Merkezi, 2010).

Alan yazın göz önüne alındığında bireylerin bilgisayar ve internet ortamında güvenliğini sağlamaya yönelik çalışmalara önem verildiği görülmektedir. Fakat yine yapılan araştırmalarda bireylerin bilişim güvenliğini tehdit eden unsurlar konusunda bilgilerinin düşük düzeyde olduğu sonucuna ulaşılmışıı (Dijle, 2006; Dijle \& Doğan 2011; Karaoğlan-Yılmaz, Yılmaz \& Sezer, 2014; Pusey \& Sadera, 2011; Shehri, 2012; Tekerek \& Mart, 2010; Tekerek \& Tekerek, 2013). Örneğin Tekerek ve Tekerek (2013) öğrencilerin güvenli şifre kullanımı, çevrimiçi güvenli iletişim, kötücül yazılım denetlemesi yapma, belge koruma, kişisel bilgisayar güvenliği, güvenlik duvarı ve filtreleme yazılımları kullanımı gibi konularda bilgilerinin düşük olduğunu tespit etmişlerdir. Ayrıca söz konusu araştırmada öğrenciler, bilgi güvenliği konusunda yeterli bilgiye sahip olmadıklarını belirtmişlerdir. Benzer şekilde Tekerek ve Mart (2010) gerçekleştirdikleri araştırmalarında öğrencilerin sırasıyla pornografi, zararlı içerikli siteler, şiddet içerikli oyunlar, sohbet yazılımları ve sosyal ağlar, teknik zararlar konusunda tehlikelerle karşılaştıklarını belirtmişlerdir. Yine söz konusu araştırmada çocukların internette birçok risk ve tehlikeyle karşılaştıkları fakat bunlara karşı gerekli farkındalığa sahip olmadıkları belirlenmiştir.

Shehri (2012) farklı kültür ve bilgi birikimine sahip 35 ülkeden 200 kullanıcı üzerinde gerçekleştirdiği araştırmasında katııımıların bazı konularda iyi düzeyde farkındalığa sahip olmalarına rağmen buna uygun şekilde davranışlar sergilemediklerini ve bazı güvenlik konularında yeterli bilgiye sahip olmadıklarını tespit etmiştir. Karaoğlan-Yılmaz ve ark. (2014) üniversite birinci sınıf üzerinde gerçekleştirdiği araştırmasında öğrencilerin bilgisayara erişim güvenliği, zararlı programlar ve korunma yolları, sosyal mühendislik, parola güvenliği, dosya erişim ve paylaşım güvenliği, internet ve ağ güvenliği, e-posta güvenliği, yedekleme yapma gibi güvenlik önlemlerinden bir ya da birkaçını derste gördüklerini güvenlikle ilgili diğer konuları ise görmediklerini tespit etmişlerdir. Kaşıkçı, Çağıltay, Karakuş, Kurşun ve Ogan (2014) Türkiye ve 23 Avrupa ülkesinin dâhil olduğu Avrupa Çevrimiçi Çocukları projesi bulgularını inceleyerek çocukların internet alışkanlıklarını ve karşılaştıkları riskleri tespit etmişlerdir. Söz konusu araştırmada çocukların aşırı internet kullanımı, cinsel içerikli fotoğraf görme, siber zorbalığa maruz 
kalma, cinsel içerikli mesaj alma, internet üzerinden yeni kişilerle tanışma gibi çevrimiçi risklerle karşılaştıkları görülmüştür. Pusey ve Sadera (2011) ABD’de gerçekleştirdikleri araştırmada öğretmen adaylarının bilişim güvenliği konularını bilme ve bunları öğretebilme düzeylerini incelemişlerdir. Araştırma sonuçları, öğretmen adaylarının bilişim güvenliği konusunda sınıfı bilgiye sahip olduklarını ve kendilerini bu konuları öğretmede yetersiz gördüklerini ortaya koymuştur.

Bilişim güvenliği konusuna yönelik gerçekleştirilen araştırmalarda bireylere küçük yaşlardan itibaren eğitimlerin verilmesinin, bilişim güvenliğini sağlamaya yönelik dersin okullarda okutulmasının, seminerler ve kitle iletişim araçlarıyla bilinçlendirme faaliyetlerinin yapılmasının gerekliliği üzerinde durulmuştur Gerçekleştirilen araştırma sonuçları dikkate alındığında günümüzde özellikle öğrencilerin bilgisayar (Mart, 2012; Ögütçü, 2010). ve interneti güvenli bir şekilde kullanabilmeleri önemli bir konudur. Bireylerin farkındalıklarının ve bilgilerinin düşük düzeyde olması itibariyle okullarda küçük yaşlardan itibaren bilgi ve bilişim güvenliğine yönelik bilinçlendirme faaliyetlerine önem verilmesi gerekmektedir. Bu açıdan bakıldığında öğrencileri bu konularda bilgilendirecek ve gerekli güvenlik tedbirlerinin nasıl alınması gerektiğini anlatacak olan Bilgisayar ve Öğretim Teknolojileri Eğitimi (BÖTE) öğretmen adaylarına büyük görevler ve sorumluluklar düşmektedir.

Uluslararası Eğitimde Teknoloji Topluluğu'nun (International Society for Technology in EducationISTE) yayınladığı Ulusal Eğitim Teknolojisi Standartlarında (The National Educational Technology Standards-NETs) öğretmenlerin, etik konularda model olma; bilginin ve teknolojinin kullanımında sosyal etkileşimden sorumlu olma; dijital bilginin ve teknolojinin güvenli, yasal ve etik kullanımını destekleme ve öğretme becerilerine sahip olmaları gerektiği ifade edilmektedir (ISTE, 2008). Ayrıca ülkemizde Milli Eğitim Bakanlığı (MEB) tarafından belirlenen bilişim teknolojileri özel alan yeterliliklerinde, bilişim teknolojileri öğretmenlerinin; bilişim teknolojileri, internet ve ağ teknolojilerinde yasal kuralları bilme, etik davranma, güvenli kullanabilme, güvenlik tehditlerine karşı güvenlik stratejileri geliştirme ve bilişim güvenliği konularını öğretebilme niteliklerine sahip olmaları gerektiği belirtilmiştir (MEB, 2008). Dolayısıyla artan bilişim güvenliği tehditleri, ISTE standartları ve MEB özel alan yeterlilikleri dikkate alındığında okullarda görev yapacak olan BÖTE öğretmen adaylarının bilişim güvenliği bilgilerinin incelenmesinin önemli olduğu düşünülmektedir. Bu çalışmanın amacı BÖTE öğretmen adaylarının;

1-) Bilişim güvenliği bilgilerinin ne düzeyde olduğunun,

2-) Bilişim güvenliği bilgilerinin;

a) Yaş,

b) Cinsiyet,

c) Bilişim güvenliğine yönelik bir kurs veya ders alıp almama,

d) Sinıf,

e) Bilgisayara sahip olma süresi,

f) Günlük bilgisayar kullanım süresi,

g) Günlük internet kullanım süresi,

h) Öğrenim görülen üniversite değişkenlerine göre anlamlı bir farklılık gösterip göstermediğinin tespit edilmesidir.

\section{Yöntem}

\section{Araştırma Modeli}

$\mathrm{Bu}$ çalışma, nicel araştırma yöntemlerinden tarama modeli ile gerçekleştirilmiştir. Tarama araştırmaları, bir konu veya olaya yönelik katılımcıların görüşlerinin, tutumlarının, becerilerinin, yeteneklerinin belirlendiği araştırma türü olarak bilinmektedir. Bu araştırma türünün amacı genelde var 
olan durumun fotoğrafını çekerek betimleme yapmaktır (Büyüköztürk, Kılıç Çakmak, Akgün, Karadeniz \& Demirel, 2012). Dolasıyla bu araştırmada BÖTE öğretmen adaylarının bilişim güvenliği bilgilerinin çeşitli değişkenlere göre farklılaşıp farklılaşmadığının tespit edilmesi amaçlanmıştır.

\section{Çalışma Grubu}

Bu araştırmanın çalışma grubunu, 2013-2014 eğitim-öğretim yılı Sakarya, Amasya, Erzincan ve Siirt Üniversitelerinin BÖTE bölümünde okuyan üçüncü ve dördüncü sınıf öğretmen adayları oluşturmaktadır. Araştırma, bu üniversitelerin üçüncü ve dördüncü sınıflarında okuyan 375 lisans öğrencisi üzerinde gerçekleştirilmiştir. Araştırma, dört üniversitede görev yapmakta olan ve çalışmanın gerçekleştirilmesini destekleyen öğretim elemanlarının yardımı ile yapılmıştır. Ayrıca BÖTE lisans programında bulunan dersler ve araştırmanın konusu dikkate alındığında programın sağladığı yeterlilikleri belirleme ve alınan eğitimin bir değişim oluşturup oluşturmadığını görme açısından son sınıflarla birlikte üçüncü sınıfların çalışma grubunu oluşturması uygun görülmüştür. Bu çalışmada elde edilen sonuçlar, araştırmanın gerçekleştirildiği dört üniversite ile sınırlıdır. Çalışma grubunun belirlenmesinde uygulama kolaylığı dışında bir değişken dikkate alınmamıştır. Çalışmanın uygulandığı üniversitelere ve öğrenci sayılarına Tablo 1'de yer verilmiştir.

Tablo 1.

BÖTE Öğretmen Adaylarının Üniversite ve Sınıflarına Göre Dağılımları

\begin{tabular}{lcc}
\hline Üniversiteler & 3.Sınıf & 4.Sınıf \\
\hline Sakarya Üniversitesi & 10 & 117 \\
Amasya Üniversitesi & 45 & 38 \\
Erzincan Üniversitesi & 41 & 66 \\
Siirt Üniversitesi & 34 & 24 \\
Toplam & 130 & 245 \\
\hline
\end{tabular}

Öğretmen adaylarının yaş ve cinsiyete yönelik bulgular ise Tablo 2'de verilmiştir.

Tablo 2.

BÖTE Öğretmen Adaylarının Demografik Özellikleri

\begin{tabular}{lccc}
\hline Özellik & Gruplar & Yüzde & Frekans \\
\hline Yaş & 20 & 27 & 7,2 \\
& 21 & 96 & 25,6 \\
& 22 & 115 & 30,7 \\
& 23 & 86 & 22,9 \\
& 24 & 35 & 9,3 \\
& 25 ve üzeri & 16 & 4,3 \\
\hline Cinsiyet & Kadın & 173 & 46,1 \\
& Erkek & 202 & 53,9 \\
\hline
\end{tabular}

\section{Veri Toplama Aracı}

Bu araştırmada veri toplama aracı olarak Pusey ve Sadera (2011) tarafından geliştirilen "Bilişim Güvenliği Bilgisi" anketi kullanılmıştır. Anket, demografik ve çoktan seçmeli bilişim güvenliği bilgi sorularından oluşmaktadır. Anket, uzman görüşü alınarak Türkçeye uyarlanmıştır. Ankette yer alan soruların kapsam geçerliliğini ve Türkçe çevirinin doğruluğunu gerçekleştirmek uzman görüşü alınmıştır. Eğitim Fakültesi BÖTE bölümünden doktorasını tamamlamış üç, Yönetim Bilişim Sistemlerinde bilişim güvenliği konusunda doktora yapan bir, bilişim suçları konusunda doktorasını tamamlamış bir ve Sakarya 
Emniyet Müdürlüğü siber suçlarlar mücadele şube müdürlüğünden bir kişi olmak üzere toplam altı kişiden uzman görüşü alınmıştır. Anket soruları özellikle günümüzde önemli güvenlik konuları olan eposta güvenliği, e-posta ekleri, Vekil sunucuları (Proxy Server), reklam pencereleri (Pop-Up Ads), USB taşınabilir bellek (Flash) gibi depolama aygıtlarının güvenli kullanımı, güvenlik duvarı, güvenli şifre oluşturma konularını barındırmaktadır. Uzmanlar, genel olarak adayların bilişim güvenliği bilgilerini ölçen bu anket sorularının kapsamını uygun ve yeterli bulduklarını belirtmişlerdir. Ayrıca temel alınan özgün ölçek uzman görüşlerine dayalı olarak geçerli bir yapıya sahiptir ve uluslararası alan yazında yayımlanmıştır. Veri toplama aracının ilk bölümünde BÖTE öğretmen adaylarının yaş, cinsiyet, sınıf, günlük bilgisayar ve internet kullanım süresi, sık kullanılan bilgisayarın sahibinin kim olduğu ve ne kadar zamandır kişisel bilgisayara sahip olduklarını belirleyen sorular bulunmaktadır. Anketin ikinci bölümünde adayların bilişim güvenliği bilgilerini ölçen yedi çoktan seçmeli bilgi sorusu bulunmaktadır. Pusey ve Sadera (2011) bu sorularda adayların tahmin yürütmesini önlemek ve bilgilerini ne olduğunu tam anlamıyla ölçmek amacıyla "bilmiyorum" seçeneğine de yer vermişlerdir.

\section{Verilerin Toplanması}

Araştırma verilerin toplanması için Sakarya Üniversitesi Eğitim Fakültesi Dekanlığından izin yazısı alınmıştır. Bu izin yazısı diğer üniversitelerde verileri toplayacak öğretim elemanlarına gönderilmiştir. Veri toplama aracı, aralık ve mart ayı arasında dersi veren öğretim elemanlarından izin alınarak ders saatinin başında öğretmen adaylarına uygulanmıştır. Veriler toplandıktan sonra eksik veya rastgele doldurulduğu tespit edilen toplam 21 anket formu araştırmadan çıkarılmıştır.

\section{Verilerin Analizi}

BÖTE öğretmen adaylarının bilişim güvenliği bilgi sorularına verdikleri cevaplar yüzde ve frekans şeklinde verilmiştir. Ayrıca BÖTE öğretmen adaylarının bilişim güvenliği bilgilerini ölçen yedi çoktan seçmeli soru için toplam puan hesaplanmıştır. Adayların bilişim güvenliği toplam puanları incelendiğinde verilerin normal dağılım göstermediği görülmüştür. Dolasıyla verilerin analiz edilmesinde normallik varsayımını gerektirmeyen Mann Whitney U-Testi kullanılmıştır (Büyüköztürk, 2012). Bu testle BÖTE öğretmen adaylarının bilişim güvenliği bilgisi toplam puanlarının; cinsiyet, sınıf ve bilişim güvenliğine yönelik eğitim alıp almama durumuna göre anlamlı farklılık gösterip göstermediği incelenmiştir. Yine normallik varsayımının karşılanmadı̆̆ı durumlarda ikiden fazla ilişkisiz örneklem için Kruskal Wallis $\mathrm{H}$ Testi kullanılmıştır (Büyüköztürk, 2012). Bu testle BÖTE öğretmen adaylarının bilişim güvenliği bilgisi toplam puanlarının; yaş, bilgisayara sahip olma süresi, günlük bilgisayar kullanım süresi, günlük internet kullanım süresi ve öğrenim görülen üniversiteye göre anlamlı bir farklılık gösterip göstermediği incelenmiştir. Verilerin analizinde IBM SPSS Statistics 22 programı kullanılmış ve anlamlılı düzeyi ,05 olarak kabul edilmiştir.

\section{Bulgular}

\section{BÖTE Öğretmen Adaylarının Bilişim Güvenliği Bilgi Sorularına Verdikleri Cevaplara Yönelik Bulgular ve Yorumlar}

Bu bölümde BÖTE öğretmen adaylarının bilişim güvenliği bilgi sorularına verdikleri cevaplara yönelik bulgulara yer verilmiştir. Tablolarda soruların doğru cevabı * işareti ile gösterilmiştir.

BÖTE öğretmen adaylarının "Virüs araması yapmadan e-posta ekini açmak ... güvenlidir." sorusuna verdikleri cevaplar Tablo 3’te verilmiştir. 
Tablo 3.

Virüs Taraması Yapmadan E-Posta Ekini Açmaya Yönelik Bilgi Sorusu Bulguları

\begin{tabular}{lcc}
\hline & Frekans (f) & Yüzde (\%) \\
\hline Güvenilir kaynaktan geldiği zaman & 239 & 63,7 \\
Bir banka veya ticari kuruluştan geldiği zaman & 9 & 2,4 \\
Konu satırı hakkınızda kişisel bilgi içerdiği zaman & 9 & 2,4 \\
Yukarıdakilerden hepsi & 30 & 8,0 \\
Hiçbiri* & 57 & 15,2 \\
Bilmiyorum & 31 & 8,3 \\
\hline
\end{tabular}

Doğru Cevap*

BÖTE öğretmen adaylarının e-posta ekini açma sorusuna verdikleri cevaplar Tablo 3'te görülmektedir. Adaylarının yarısından fazlası $(\% 63,7)$ güvenilir kaynaktan geldiği zaman virüs taraması yapmadan e-posta ekini açmanın güvenli olduğunu belirtmişlerdir. Adayların \%15,2'si doğru cevap olan "hiçbiri" seçeneğini işaretlemiştir. Adayların \%8,3'ü bilmediklerini belirtmişlerdir. Adayların \%2,4'ü bir banka veya ticari kuruluştan geldiği zaman, \%2,4'ü konu satırı kendileri hakkında bilgi içerdiği zaman seçeneklerini işaretlemişlerdir. Bu bulgular, BÖTE öğretmen adaylarının büyük çoğunluğunun e-posta eklerinin güvenliğine yönelik bilgilerinin yeterli düzeyde olmadığı şeklinde yorumlanabilir.

BÖTE öğretmen adaylarının "E-Posta ekinin içinde bulunan bağlantıya (linke) tıklamak ... güvenlidir." sorusuna verdikleri cevaplar Tablo 4'te verilmiştir.

Tablo 4.

E-Posta Eki Iç̧indeki Bağlantıya Tıklamaya Yönelik Bilgi Sorusu Bulguları

\begin{tabular}{lcc}
\hline & Frekans (f) & Yüzde (\%) \\
\hline Güvenilir kaynaktan geldiği zaman & 239 & 63,7 \\
Bir banka veya ticari kuruluştan geldiği zaman & 15 & 4,0 \\
Konu satırı hakkınızda kişisel bilgi içerdiği zaman & 7 & 1,9 \\
Yukarıdakilerden hepsi & 31 & 8,3 \\
Hiçbiri* & 61 & 16,3 \\
Bilmiyorum & 22 & 5,9 \\
\hline Doğru Cevap* &
\end{tabular}

Tablo 4'te BÖTE öğretmen adaylarının e-posta eki içerisindeki bağlantıya tıklanması sorusuna verdikleri cevaplar görülmektedir. Adayların \%63,7"si güvenilir kaynaktan geldiği zaman e-posta eki içinde bağlantıya tıklamanın güvenli olduğunu, \%4'ü bir banka veya ticari kuruluştan geldiği zaman eposta eki içinde bağlantıya tıklamanın güvenli olduğunu, \%1,9’u konu satırı hakkınızda kişisel bilgi içerdiği zaman e-posta eki içinde bağlantıya tıklamanın güvenli olduğunu, \%8,3'ü yukarıdaki seçeneklerin hepsinin güvenli bir yöntem olduğunu, \%16,3'ü doğru cevap olan hiçbirinin güvenli olmadığını ve \%5,9'u ise bilmediklerini belirtmişlerdir. Bu bulgular, BÖTE öğretmen adaylarının büyük çoğunluğunun e-posta eki içerisindeki bağlantıya tıklama güvenliğine yönelik bilgilerinin yeterli düzeyde olmadığı şeklinde yorumlanabilir.

BÖTE öğretmen adaylarının Vekil (Proxy) sunucunun görevine yönelik soruya verdikleri cevaplar Tablo 5'te verilmiştir. 
Tablo 5.

Vekil (Proxy) Sunucunun Görevine Yönelik Bilgi Sorusu Bulguları

\begin{tabular}{lcc}
\hline & Frekans (f) & Yüzde (\%) \\
\hline Çocukları çevrimiçi müstehcen içerikten korur. & 45 & 12,0 \\
Çocukların okulda internet filtrelerini atlamalarına izin verir. & 27 & 7,2 \\
Web Siteleri için güvenli şifre oluşturur. & 113 & 30,1 \\
Yukarıdakilerden hepsi* & 60 & 16,0 \\
Hiçbiri & 21 & 5,6 \\
Bilmiyorum & 109 & 29,1 \\
\hline
\end{tabular}

Doğru Cevap*

Tablo 5'te BÖTE öğretmen adaylarının vekil sunucuların görevinin ne olduğuna yönelik soruya verdikleri cevaplar görülmektedir. Adayların \%12'si çocukları çevrimiçi müstehcen içerikten koruduğunu, $\% 7,2$ 'si çocukların okulda internet filtrelerini atlamalarında izin verdiğini, $\% 30,1^{\prime}$ i web siteleri için güvenli şifre oluşturduğunu, \%16'sı yukarıdaki seçeneklerin hepsini sağladığını, \% 5,6'sı hiçbir seçeneğin vekil sunucusunun görevi olmadığını, \%29,1'i görevinin ne olduğunu bilmediklerini belirtmişlerdir. Vekil sunucusu ilk üç seçenekteki özellikleri gerçekleştirmektedir. Dolayısıla bu bulgular, öğretmen adaylarının vekil sunucusunun işlevleri konusunda eksik bilgiye sahip olduklarını göstermektedir. Ayrıca "bilmiyorum" seçeneğini işaretleyenlerin oranına bakıldığında $(\% 29,1)$ konu hakkında bilgi sahibi olmayanların oranın beklenenden yüksek olduğu görülmektedir.

BÖTE öğretmen adaylarının yeni pencerede (ekranda) açılan reklam pencerelerinin (Pop-up Ads) ne zaman görüntülendiğine yönelik soruya verdikleri cevaplar Tablo 6'da verilmiştir.

Tablo 6.

Reklam Pencerelerine (Pop-Up Ads) Yönelik Bilgi Sorusu Bulguları

\begin{tabular}{lcc}
\hline & Frekans (f) & Yüzde (\%) \\
\hline Web sitelerinde sörf yaparken görüntülenir. & 146 & 38,9 \\
Web sitelerini ziyaret ettikten sonra görüntülenir. & 52 & 13,9 \\
Internet tarayıcısı açıldığı zaman görüntülenir. & 50 & 13,3 \\
Yukarıdakilerden hepsi & 73 & 19,5 \\
Hiçbiri* & 14 & 3,7 \\
Bilmiyorum & 40 & 10,7 \\
\hline
\end{tabular}

Doğru Cevap*

Tablo 6' da BÖTE öğretmen adaylarının reklam pencerelerinin (Pop-up Ads) görüntülenmesine yönelik soruya verdikleri cevaplar görülmektedir. Adayların $\% 38,9^{\prime} u$ web sitelerinde sörf yaparken görüntülendiğini, \%13,9'u web sitelerini ziyaret ettikten sonra görüntülendiğini, \%13,3'ü internet tarayıcısı açıldığı zaman görüntülendiğini, \%19,5'i yukarıdaki seçeneklerde yapılan her işlemin bu pencerelerin görüntülenmesine neden olduğunu, \%3,7'si yukarıdaki belirtilen işlemlerin bu pencerelerin görüntülenmesine neden olmadığını, \%10,7'si bilmediklerini belirtmişlerdir. Reklam pencerelerin güvenli olmayan sitelerde gezinirken veya güvenli olmayan bir bağlantıya tıklanınca görüntülendiği göz önüne alındığında doğru olan "hiçbiri" seçeneğini işaretleyenlerin yüzdesinin $(\% 3,7)$ düşük çıktığı görülmektedir.

BÖTE öğretmen adaylarının USB (Flash) bellek gibi taşınabilir veri depolama aygıtları ne tür amaçlar için kullanılabileceğine yönelik soruya verdikleri cevaplar Tablo 7'de verilmiştir. 
Ömer Faruk GÖKMEN ve Özcan Erkan AKGÜN - Çukurova Üniversitesi Eğitim Fakültesi Dergisi, 44(1), 2014, 61-84

Tablo 7.

Taşınabilir Veri Depolama Aygıtlarında Saklanan Verilere Yönelik Bilgi Sorusu Bulguları

\begin{tabular}{lcc}
\hline & Frekans (f) & Yüzde (\%) \\
\hline Öğrenci isimleri, adresleri, test puanları gibi verileri & 12 & 3,2 \\
Öğrenci çalışmalar & 65 & 17,3 \\
Bireylerin eğitim planları & 8 & 2,1 \\
Yukarıdakilerden hepsi & 275 & 73,3 \\
Hiçbiri* & 11 & 2,9 \\
Bilmiyorum & 4 & 1,1 \\
\hline
\end{tabular}

Doğru Cevap*

Tablo 7'de USB bellek gibi taşınabilir aygıtların ne tür amaçlar için kullanılabileceğine yönelik soruya verdikleri cevaplar görülmektedir. Adayların büyük çoğunluğu $(\% 73,3)$ bu taşınabilir aygıtların öğrencilerin kişisel bilgilerini, öğrencilerin çalışmalarını ve bireylerin eğitim planları gibi verileri depolamak için kullanılabileceğini belirtmişlerdir. Çok düşük oranda aday $(\% 2,9)$ doğru seçenek olan "hiçbiri" seçeneğini işaretlemişlerdir. Bu bulgular, adayların USB bellek gibi taşınabilir aygıtlar ile öğrencilerin kişisel bilgilerinin, çalışmalarının taşınmasının bir suç olduğunu bilmediklerini göstermektedir.

BÖTE öğretmen adaylarının güvenlik duvarının görevine yönelik soruya verdikleri cevaplar Tablo 8'de verilmiştir.

\section{Tablo 8.}

Güvenlik Duvarının Görevine Yönelik Bilgi Sorusu Bulguları

\begin{tabular}{lcc}
\hline & Frekans (f) & Yüzde (\%) \\
\hline Bir bilgisayara izinsiz girişi önler. & 84 & 22,4 \\
Bilgisayardan gönderilen yetkisiz bir bilgiyi engeller. & 92 & 24,5 \\
Yukarıdakilerden hepsi* & 179 & 47,7 \\
Hiçbiri & 8 & 2,1 \\
Bilmiyorum & 12 & 3,2 \\
\hline
\end{tabular}

Doğru Cevap*

Tablo 8'de BÖTE öğretmen adayların güvenlik duvarının görevine yönelik soruya verdikleri cevaplar görülmektedir. Adayların \%22,4'ü güvenlik duvarının bir bilgisayara izinsiz girişi önlediğini, \% 24,5’i bilgisayardan gönderilen yetkisiz bilgiyi engellediğini, \%47,7'si iki seçeneği de gerçekleştirdiğini, \%2,1'i hiçbirinin güvenlik duvarının görevi olmadığını, \%3,2'si güvenlik duvarının görevinin ne olduğunu bilmediklerini belirtmişlerdir. Güvenlik duvarı, bir bilgisayara dışardan yetkisiz bir girişi ve izinsiz bilgi akışını önleyen bir yazılımdır. Dolayısıyla bu bulgular, bazı adayların güvenlik duvarının görevinin tam olarak ne olduğu konusunda eksik bilgilerinin olduğunu göstermektedir. Katılımcıların yaklaşık yarısı bu soruyu doğru cevaplamışlardır.

BÖTE öğretmen adaylarının şifrelerin nasıl olması gerektiğine yönelik soruya verdikleri cevaplar Tablo 9'da verilmiştir. 
Tablo 9.

Şifrelerin Nasıl Olması Gerektiğine Yönelik Bilgi Sorusu Bulguları

\begin{tabular}{lcc}
\hline & Frekans (f) & Yüzde (\%) \\
\hline Tüm hesaplar için aynı & 57 & 15,2 \\
Küçük-büyük harflerin ve numaraların karışımı* & 261 & 69,6 \\
Gerçek kelimeler & 11 & 2,9 \\
Yukarıdakilerden hepsi & 33 & 8,8 \\
Hiçbiri & 13 & 3,5 \\
\hline
\end{tabular}

Doğru Cevap*

Tablo 9'da BÖTE öğretmen adaylarının şifrelerin nasıl olması gerektiği konusuna verdikleri cevaplar görülmektedir. Adaların büyük çoğunluğu $(69,6)$ şifrelerin küçük-büyük harflerin ve numaraların karışımı olması, \%15,2'si aynı olması, \%2,9’u gerçek kelimelerden oluşması gerektiğini belirtmişlerdir. Bu bulgular, adayların çoğunun güvenli şifrelerin nasıl olması gerektiği konusunda bilgi sahibi olduklarını göstermektedir. Ancak yaklaşık \%30'luk kesimin bu konuda bilgilendirmeye ihtiyaç duyduğu düşünülmektedir.

\section{BÖTE Öğretmen Adaylarının Bilişim Güvenliği Bilgisi Toplam Puanlarının Çeşitli Değişkenlere Göre Farklılaşıp Farklılaşmadığına Yönelik Bulgular ve Yorumlar}

Bu bölümde BÖTE öğretmen adaylarının bilişim güvenliği bilgilerinin; yaşa, cinsiyete, sınıfa, öğrenim görülen üniversiteye, bilişim güvenliğine yönelik bir ders veya kurs alınıp alınmama durumuna, günlük bilgisayar kullanım süresine, günlük internet kullanım süresine ve bilgisayara sahip olma süresine göre anlamlı farklılık gösterip göstermediğine yönelik bulgulara yer verilmiştir.

\section{BÖTE Öğretmen Adaylarının Bilişim Güvenliği Bilgilerinin Yaşa Göre Farklılaşıp Farklılaşmadığına Yönelik Bulgular ve Yorumlar}

BÖTE öğretmen adaylarının bilişim güvenliği bilgilerinin yaşa göre farklılaşıp farklılaşmadığına yönelik bulgular ve yorumlar tablo 10 'da verilmiştir.

\section{Tablo 10.}

Bilişim Güvenliği Bilgisinin Yaş Değişkenine Göre Kruskal Wallis Sonucu

\begin{tabular}{lccccc}
\hline Yaş & N & Sıra Ortalaması & sd & $\chi^{2}$ & $p$ \\
\hline 20 & 27 & 206,00 & 5 & 7,45 &, 189 \\
21 & 96 & 179,86 & & & \\
22 & 115 & 180,50 & & & \\
23 & 86 & 183,53 & & & \\
24 & 35 & 226,66 & & & \\
25 ve üzeri & 16 & 199,84 & & & \\
\hline
\end{tabular}

Tablo 10 incelendiğinde adayların bilişim güvenliği testinden aldıkları puanların, yaşlarına bağlı olarak anlamlı farklılık göstermemektedir $[\chi 2(s d=5, n=375)=7,45, p>, 05]$. Bu bulgu, yaşın öğretmen adaylarının bilişim güvenliği bilgilerinde bir farklılığa neden olmadığını göstermektedir. 


\section{BÖTE Öğretmen Adaylarının Bilişim Güvenliği Bilgilerinin Cinsiyete Göre Farklılaşıp Farklılaşmadığına Yönelik Bulgular ve Yorumlar}

BÖTE öğretmen adaylarının bilişim güvenliği bilgilerinin cinsiyete göre farklılaşıp farklılaşmadığına yönelik bulgular ve yorumlar Tablo 11'de verilmiştir.

\section{Tablo 11.}

Bilişim Güvenliği Bilgisinin Cinsiyete Göre U-Testi Sonucu

\begin{tabular}{lcccccc}
\hline Cinsiyet & $\mathrm{N}$ & Sıra Ortalaması & Sıra Toplamı & $\mathrm{U}$ & $\mathrm{p}$ & $d$ \\
\hline Kadın & 173 & 170,48 & 29492,50 & 14441,50 &, 002 & 0,15 \\
Erkek & 202 & 203,01 & 41007,50 & & & \\
\hline
\end{tabular}

Öğretmen adaylarının bilişim güvenliği testinden aldıkları puanların Mann Whitney U-testi sonuçları Tablo 11 'de verilmiştir. Tablo $18^{\prime}$ de adayların bilişim güvenliği bilgi puanlarının cinsiyete göre anlamlı farklılık gösterdiği görülmektedir [U:14441,50, $p<, 05]$. Ayrıca $d=0,15$ hesaplanmıştır. Bu değer 0,2 den küçük olduğu için etki büyüklüğünün düşük seviyede olduğu söylenebilir (Green \& Salkind, 2008). Sıra ortalamaları dikkate alındığında, erkek öğretmen adaylarının kadın öğretmen adaylarına göre bilişim güvenliği bilgi puanlarının daha yüksek olduğu anlaşılmaktadır. Bir diğer ifade ile bilişim güvenliği açısından erkek öğretmen adaylarının bilgi düzeyleri kadın öğretmen adaylarına göre daha yüksektir.

BÖTE Öğretmen Adaylarının Bilişim Güvenliği Bilgilerinin Bilişim Güvenliğine Yönelik Eğitim Alıp Almadıklarına Göre Farklılaşıp Farklılaşmadığına Yönelik Bulgular ve Yorumlar

BÖTE öğretmen adaylarının bilişim güvenliği bilgilerinin bilişim güvenliğine yönelik eğitim alıp almadıklarına göre farklılaşıp farklılaşmadığına yönelik bulgular ve yorumlar Tablo 12'de verilmiştir.

Tablo 12.

Bilişim Güvenliği Bilgisinin Bilişim Güvenliğine Yönelik Eğitim Alıp Almama Durumuna Göre U-Testi Sonucu

\begin{tabular}{lccccc}
\hline Grup & $\mathrm{N}$ & Sıra Ortalaması & Sıra Toplamı & U & $\mathrm{p}$ \\
\hline Evet & 114 & 194,21 & 22139,50 & 14169,50 &, 437 \\
Hayır & 261 & 185,29 & 48360,50 & & \\
\hline
\end{tabular}

Tablo 12 incelendiğinde adaylarının bilişim güvenliği bilgi puanları, bu konuya yönelik herhangi bir eğitim alıp almama durumlarına göre anlamlı farklılık göstermemektedir [U:14169,50, p>,05]. Sıra ortalamalarına bakıldığında, bilişim güvenliğine yönelik eğitim alanlar ile almayanlar arasında çok büyük bir fark olmadığı görülmektedir. Bu bulgu, bilişim güvenliğine yönelik eğitim alan adayların bilgi düzeylerinin, bu eğitimleri almayan adayların bilgi düzeylerine göre bir farklılaşma oluşturmadığını göstermektedir. Ayrıca yine bu bulgulara göz önüne alınarak bilişim güvenliğine yönelik verilen eğitimlerin, adayların bilgilerini ve yeterliliklerini artıracak bir düzeyde ve içerikte olmadığı yönünde bir yorum yapılabilir. Ancak bu bulgunun daha iyi anlaşılabilmesi için katılımcıların hangi dersleri aldıklarının tespit edilmesini sağlayacak nitel bulgulara ihtiyaç duyulmaktadır. 
BÖTE Öğretmen Adaylarının Bilişim Güvenliği Bilgilerinin Sınıfa Göre Farklılaşıp Farkıılaşmadığına Yönelik Bulgular ve Yorumlar

BÖTE öğretmen adaylarının bilişim güvenliği bilgilerinin sınıfa göre farklılaşıp farklılaşmadığına yönelik bulgular ve yorumlar Tablo 13'te verilmiştir.

\section{Tablo 13.}

Bilişim Güvenliği Bilgisinin Sınıf Değişkenine Göre U-Testi Sonucu

\begin{tabular}{lccccc}
\hline Sinıf & $\mathrm{N}$ & Sira Ortalaması & Sira Toplamı & $\mathrm{U}$ & $\mathrm{p}$ \\
\hline 3 & 130 & 182,73 & 23754,50 & 15239,50 &, 467 \\
4 & 245 & 190,80 & 46745,50 & & \\
\hline
\end{tabular}

Tablo 13'te adayların bilişim güvenliği bilgilerinin sınıf değişkeni göre anlamlı farklılık oluşturup oluşturmadığına yönelik bulgulara yer verilmiştir. Tablo 13 incelendiğinde adayların bilişim güvenliği bilgilerinin sınıf düzeyine göre anlamlı farklılık oluşturmadığı görülmektedir [U:15239,50, p>,05]. Bu bulgu, sınıf düzeyinin öğretmen adaylarının bilişim güvenliği bilgilerinde bir farklılı̆a neden olmadığını göstermektedir. Bu bulgu, hali hazırdaki lisans programlarının üçüncü ve dördüncü sınıflarında öğretmen adaylarının doğrudan bilişim güvenliğini sağlamaya yönelik zorunlu bir dersin olmayışına bağlanabilir.

BÖTE Öğretmen Adaylarının Biliş̧im Güvenliği Bilgilerinin Günlük Bilgisayar Kullanım Süresine Göre Farklılaşıp Farklılaşmadığına Yönelik Bulgular ve Yorumlar

BÖTE öğretmen adaylarını bilişim güvenliği bilgilerinin günlük bilgisayar kullanım süresine göre farklılaşıp farklılaşmadığına yönelik bulgular ve yorumlar Tablo 14'te verilmiştir.

Tablo 14.

Bilişim Güvenliği Bilgisinin Günlük Bilgisayar Kullanım Süresi Değişkenine Göre Kruskal Wallis Sonucu

\begin{tabular}{lccccc}
\hline Günlük Bilgisayar Kullanım Süresi & $\mathrm{N}$ & Sıra Ortalaması & $\mathrm{sd}$ & $\chi^{2}$ & $\mathrm{p}$ \\
\hline 1-3 saat & 153 & 180,95 & 2 & 1,25 &, 536 \\
4-6 saat & 134 & 192,10 & & & \\
7 saat ve üzeri & 88 & 194,01 & & & \\
\hline
\end{tabular}

Adayların günlük bilgisayar kullanım sürelerine göre bilişim güvenliği testinden aldıkları puanların Kruskall Wallis testi sonuçları Tablo 14'te verilmiştir. Tablo 14 incelendiğinde, adayların bilişim güvenliği testinden aldıkları puanların, günlük bilgisayar kullanım süresine göre anlamlı farklıık göstermemektedir [X2 $(s d=2, n=375)=1,25, p>, 05]$. Yani bilgisayarı az ya da çok kullanmak bilişim güvenliği bilgilerini değiştirmemektedir.

BÖTE Öğretmen Adaylarının Bilişim Güvenliği Bilgilerinin Günlük Internet Kullanım Süresine Göre Farklılaşıp Farklılaşmadığına Yönelik Bulgular ve Yorumlar

BÖTE öğretmen adaylarının bilişim güvenliği bilgilerinin günlük internet kullanım süresine göre farklılaşıp farklılaşmadığına yönelik bulgular ve yorumlar Tablo $15^{\prime}$ te verilmiştir. 
Ömer Faruk GÖKMEN ve Özcan Erkan AKGÜN - Çukurova Üniversitesi Eğitim Fakültesi Dergisi, 44(1), 2014, 61-84

Tablo 15.

Bilişim Güvenliği Bilgisinin Günlük Internet Kullanım Süresi Değişkenine Göre Kruskal Wallis Sonucu

\begin{tabular}{lccccc}
\hline \multicolumn{1}{c}{ Günlük Internet Kullanım Süresi } & $\mathrm{N}$ & Sıra Ortalaması & sd & $\chi^{2}$ & $\mathrm{p}$ \\
\hline 1 saatten az & 55 & 175,38 & 3 & 2,59 &, 458 \\
$2-3$ saat & 163 & 187,39 & & & \\
4-6 saat & 106 & 199,67 & & & \\
7 saat ve üzeri & 51 & 179,32 & & & \\
\hline
\end{tabular}

Tablo 15 incelendiğinde, adayların bilişim güvenliği testinden aldıkları puanların, günlük internet kullanım süresine göre anlamlı farklılık göstermemektedir [ $\chi 2(s d=3, n=375)=2,59, p>, 05]$. Bu bulgu, günlük internet kullanım süresinin öğretmen adayların bilişim güvenliği bilgilerinde her hangi bir farkılışma yaratmadığını göstermektedir.

BÖTE Öğretmen Adaylarının Bilişim Güvenliği Bilgilerinin Öğrenim Görülen Üniversiteye Göre Farklılaşıp Farklılaşmadığına Yönelik Bulgular ve Yorumlar

BÖTE öğretmen adaylarının bilişim güvenliği bilgilerinin öğrenim görülen üniversiteye göre farklılaşıp farklılaşmadığına yönelik bulgular ve yorumlar Tablo 16'da verilmiştir.

Tablo 16.

Bilişim Güvenliği Bilgisinin Öğrenim Görülen Üniversite Değişkenine Göre Kruskal Wallis Sonucu

\begin{tabular}{lccccccc}
\hline Üniversiteler & $\mathrm{N}$ & Sıra Ortalaması & $\mathrm{sd}$ & $\chi^{2}$ & $\mathrm{p}$ & Anlamlı Fark & $\eta^{2}$ \\
\hline Erzincan & 107 & 173,97 & 3 & 14,16 &, 003 & $\begin{array}{c}\text { Sakarya > Erzincan } \\
\text { Sakarya > Siirt }\end{array}$ & 0,53 \\
Siirt & 58 & 153,61 & & & & Amasya > Siirt & \\
Amasya & 83 & 204,00 & & & & & \\
Sakarya & 127 & 205,07 & & & & & \\
\hline
\end{tabular}

Tablo 16 incelendiğinde, adayların bilişim güvenliği bilgilerinin, öğrenim gördükleri üniversitelere göre anlamlı farklılık gösterdiği görülmektedir [ $\chi 22(s d=3, n=375)=14,16, p<.05]$. Grupların sıra ortalamalarına bakıldığında Sakarya Üniversitesi'nde okuyan öğrencilerin bilişim güvenliği bilgilerinin en yüksek değere sahip olduğu, bu üniversiteyi sırasıyla Amasya, Erzincan ve Siirt Üniversitelerinin takip ettiği görülmektedir. Anlamlı farklılığın hangi üniversiteler arasında olduğuna bakıldığında ise Sakarya Üniversitesi ile Erzincan Üniversitesi, Sakarya Üniversitesi ile Siirt Üniversitesi, Amasya Üniversitesi ile Siirt Üniversitesi arasında olduğu belirlenmiştir. Ayrıca $\rceil 2=0,53$ hesaplanmıştır. Bu değer ,14'den büyük olduğu için etki büyüklüğünün yüksek seviyede olduğu söylenebilir (Green \& Salkind, 2008). Bu bulgular, öğrenim görülen üniversitenin öğretmen adaylarının bilişim güvenliği bilgilerine etki ettiğini göstermektedir. Bu farklılığın nedeni olarak öğretmen adaylarının aldıkları derslerin farklılığı, Sakarya Üniversitesi Eğitim Fakültesi BÖTE programının diğer üniversitelerinin BÖTE programından farklı olması, üniversiteye giriş puanlarının farklılığı vs. olabilir. İleride yapılacak çalışmalarda bu farklılığı oluşturan nedenleri belirlemeye yönelik nitel ve nicel çalışmalar yapılabilir. 
BÖTE Öğretmen Adaylarının Biliş̧im Güvenliği Bilgilerinin Bilgisayara Sahip Olma Süresine Göre Farklılaşıp Farklılaşmadığına Yönelik Bulgular ve Yorumlar

BÖTE öğretmen adaylarının bilişim güvenliği bilgilerinin bilgisayara sahip olma süresine göre farklılaşıp farklılaşmadığına yönelik bulgular ve yorumlar Tablo 17'de verilmiştir.

\section{Tablo 17.}

Bilişim Güvenliği Bilgisinin Bilgisayara Sahip Olma Süresine Göre Kruskal Wallis Sonucu

\begin{tabular}{lccccc}
\hline \multicolumn{1}{c}{ Bilgisayara Sahip Olma Süresi } & N & Sıra Ortalaması & sd & $\chi^{2}$ & p \\
\hline 2 yıl ve altı & 47 & 179,09 & 7 & 7,94 &, 337 \\
3 yıl & 62 & 170,40 & & & \\
4 yıl & 66 & 172,35 & & & \\
5 yıl & 36 & 203,51 & & & \\
6 yıl & 22 & 220,45 & & & \\
7 yıl & 37 & 193,46 & & & \\
8 yıl & 33 & 198,27 & & & \\
9 yıl ve üzeri & 72 & 198,14 & & & \\
\hline
\end{tabular}

Adayların bilgisayara sahip olma süresine göre bilişim güvenliği testinden aldıkları puanların Kruskall Wallis testi sonuçları Tablo $17^{\prime}$ de verilmiştir. Tablo incelendiğinde, adayların bilişim güvenliği bilgi puanlarının, bilgisayara sahip olma süresine göre anlamlı farklılık göstermediği görülmektedir [ $\chi 2 \quad(s d=7$, $\mathrm{n}=375)=7,94, \mathrm{p}>, 05]$. Bu bulgu, öğretmen adaylarının bilgisayara sahip olma süresinin bilişim güvenliği bilgilerinde her hangi bir farklılaşma yaratmadığını göstermektedir.

\section{Sonuç, Tartışma ve Öneriler}

BÖTE öğretmen adaylarının bilişim güvenliği bilgilerinin incelendiği bu araştırmada BÖTE öğretmen adayların bilişim güvenliği bilgilerinin; cinsiyet ve öğrenim görülen üniversiteye göre değiştiği tespit edilmiştir. Bilgi sorularından alınan toplam puanlar dikkate alındığında BÖTE erkek öğretmen adaylarının bilişim güvenliği bilgilerinin kadın öğretmen adaylarının bilişim güvenliği bilgilerine göre daha yüksek olduğu sonucuna ulaşılmıştır. Benzer şekilde Mart (2012) gerçekleştirdiği araştırmasında katılımcıların bilgi güvenliği farkındalığının cinsiyete göre farklılaştığı sonucuna ulaşmışır. Fakat Mart (2012)'ın araştırmasında kadın katılımcıların bilgi güvenliği farkındalı̆̆ı erkek katılımcılara göre daha yüksek çıkmışıır. Mart'ın (2012) araştırmasını mühendis, avukat vb. farklı meslek grubundan bireyler üzerinde gerçekleştirmesi bu farklılığın oluşmasında etkili olabileceği düşünülmektedir. Yine araştırma sonuçlarına göre, Sakarya Üniversitesinde okuyan BÖTE öğretmen adaylarının bilişim güvenliği bilgi düzeylerinin diğer üç üniversitede okuyan BÖTE öğretmen adaylarının bilgi düzeylerine göre daha yüksek çıktı̆̆ı sonucuna ulaşılmıştır. Bu farkııı̆ı̆ı oluşmasında üniversitelerin lisans programlarında verilen derslerin niteliğinin, içeriğinin veya farklı etmenlerin etkisinin olabileceğini akla getirmektedir. Ayrıca Sakarya Üniversitesi Eğitim Fakültesinde diğer üniversitelerin Eğitim Fakültelerinden farklı olarak 2009 yılında değiştirilen yeni program okutulmaktadır. Dolayısıyla bu üniversitelerde bu farklılı̆ın oluşmasına neden olan temel etmelerin ne olduğuna yönelik nitel araştırmaların yapılmasının faydalı olacağı düşünülmektedir.

BÖTE öğretmen adaylarının bilişim güvenliği bilgilerinin; yaşa, bilgisayara sahip olma süresine, sınıf düzeyine, günlük bilgisayar kullanım süresine, günlük internet kullanım süresine ve bilişim güvenliğine yönelik bir ders veya kursun alınıp alınmadığı durumuna göre değişmediği sonucuna ulaşıımıştır. Ancak alındığı belirtilen bilişim güvenliği derslerinin içeriği ve bu derslerin yeterliliği bu çalışmada incelenmemiştir. Bu çalışmada, yaşın öğretmen adaylarının bilişim güvenliği bilgileri üzerinde bir etkiye sahip olmadığı sonucuna ulaşılmışır. Mart (2012) çalışmasında, yaşın bilgi güvenliği farkındalığına etki 
ettiği sonucuna ulaşmıştır. Mart (2012) çalışmasını 25 ve 45 üzeri farklı meslek grubundan mühendis, avukat, öğretmen vs. bireyler üzerinde gerçekleştirmesi bu sonucu doğurduğu düşünülmektedir. Bu çalışmada günlük bilgisayar ve internet kullanım süresinin bilişim güvenliği konusunda farklııklara yol açmadığı, Mart'ın (2012) çalışmasında da bulunmuştur. Bu sonuçlar, bilgisayar ve internette geçirilen sürenin bilişim güvenliği konusunda farklılık oluşturmadığını göstermektedir. Özellikle BÖTE öğretmen adaylarının bilişim güvenliği bilgilerinin, bilişim güvenliğine yönelik bir eğitim alıp almama durumlarına göre farklılık göstermemesi şaşırtıcı bir sonuç olarak görülmektedir. Dolayısıyla bir kurs veya ders alan öğretmen adayların bir kurs veya ders almayan adaylara göre bilişim güvenliği bilgilerde bir farklılık olmaması, bu derslerin veya eğitimlerin içerik, yöntem ve konular itibariyle yetersiz olmasından kaynaklanabileceğini düşündürmektedir. Nitekim bu sonuçlar, bilişim güvenliği konusunda iyi hazırlanmış eğitimlerin şart olduğunu ve bilişim güvenliğine yönelik verilen eğitimlerin içerik, kapsam, süreç, farkındalık ve değerlendirme bakımında düzenlenmesinin gerekli olduğunu göstermektedir.

Alan yazında bireylerin bilişim teknolojilerinin güvenli kullanımına yönelik pek çok araştırma bulunmaktadır (Canbek, 2007; Çelen, Çelik \& Seferoğlu, 2011; Dijle, 2006; Dijle \& Doğan 2011; Emiral, 2004; Karaoğlan-Yılmaz et. al., 2014; Kaşıkçı et. al., 2014; Mert, Bülbül \& Sağıroğlu, 2012; Öğütçü, 2010; Pruitt-Mentle \& Pusey, 2010; Pusey \& Sadera 2011; Rezgui \& Marks, 2008; Richardson, 2009; Shehri, 2012; Tekerek \& Mart, 2010; Tekerek \& Tekerek, 2013; Valcke, Schellens, Van Keer \& Gerarts, 2007; Ünver \& Canbay, 2010). Tekerek ve Tekerek (2013) tarafından öğrencilerin bilgi güvenliği farkındalıkları üzerine gerçekleştirilen araştırmada, öğrencilerin güvenli şifre kullanımı, çevrimiçi güvenli iletişim, kötücül yazılım denetlemesi yapma, belge koruma, kişisel bilgisayar güvenliği, güvenlik duvarı ve filtreleme yazılımı kullanma gibi konularda farkındalıklarının çok düşük olduğu sonucuna ulaşılmıştır. Ayrıca yine bu araştırmada öğrenciler, bilgi güvenliği konusunda yeterli bilgiye sahip olmadıklarını belirtmişlerdir. Canbek (2007) çocukların ve gençlerin bilgisayar ve İnternet kullanımı esnasında virüs, casus yazıım gibi teknik zararlar; şiddet içeren oyunlar oynama, arkadaş edinme gibi sosyal ve psikolojik zararlar; zararlı içerikler, istismar, kötü niyetli kişiler ile temas gibi hayati zararlarla karşılaşabileceklerini belirtmektedir. Nitekim Kaşıkçı ve ark. (2014) çalışmalarında çocukların bu gibi problemlerle karşılaştıkları sonucuna ulaşması Canbek'in (2007) oluşabilecek zararlara yönelik öngörülerini destekler niteliktedir.

Dijle ve Doğan (2011) bilişim suçlarına yönelik gerçekleştirdiği araştırmasında, bireylerin bilişim suçları konularında yeterli bilince sahip olmadıklarını ve bunun yanında bilişim suçlarına neden olacak ihlallerin, öğrencilerde ve bilgisayar eğitimi almamış kişilerde daha yüksek olduğu sonucuna ulaşmışlardır. Valcke ve ark. (2007) ilköğretim öğrencilerinin güvenli internet kullanımına yönelik gerçekleştirdiği araştırmasında öğrencilerin yüksek düzeyde güvensiz internet kullandıklarını tespit etmiştir. Tekerek ve Mart (2010) 8-14 yaş grubu üzerinde gerçekleştirdiği araştırmasında çocukların internette birçok risk ve tehditle karşılaştıklarını fakat bu tehditlere karşı yeterli farkındalığa sahip olmadıklarını tespit etmişlerdir. Bu çalışmada BÖTE öğretmen adaylarının bu gibi konularda bilgilerin yeterli düzeyde olmaması öğrencilerin bilgi güvenliği bilgilerinin düşük çıkmasında etkili olabilme ihtimalini akla getirmektedir. Nitekim Tekerek ve Mart (2010) öğretmenlerin ve ebeveynlerin internette güvenliği sağlama konusunda yeterli bilinç düzeyine sahip olmadıkları sonucuna ulaşmaları bu ihtimali güçlendirmektedir. Bunun yanında bu konuda daha kapsamlı bir araştırma gerçekleştiren Kaşıkçı ve ark. (2014) ebeveynlerin çocukların karşılaşabilecekleri risklerin farkında olmadıklarını ve internette onları rahatsız edecek durumlarla başa çıkmalarını sağlayacak yardımı da sağlayamadıklarını tespit etmiştir.

Amerika Birleşik Devletleri'nde (ABD) National Cyber Security Alliance (NCSA) tarafından gerçekleştirilen araştırmada okullarda görev yapan öğretmenlerin son 12 ay içerisinde öğrencilere öğrettikleri bilişim güvenliği konularının düşük seviyede olduğu tespit edilmiştir (NCSA, 2011). PruittMentle ve Pusey (2010) bilişim güvenliğine yönelik öğretmen görüşlerinin neler olduğunu tespit ettiği araştırmasında, az sayıda öğretmenin temel internet becerilerini öğrettikleri sonucuna ulaşmıştır. Bu sonuca göre öğretmenlerin $\% 25^{\prime} \mathrm{i}$ şifre değiştirme, \%14'ü anti virüs yazılımı kullanma, \%12'si bilişim korsanlı̆̆ı, \%16'sı güvenlik duvarı, \%33'ü sosyal ağların tehlikeleri, \%39'u yabancılarla bilgi paylaşma, \%33'ü özel hayata saygı gösterme konularında öğrencilerini bilgilendirmektedirler. 24 Avrupa ülkesinde 
gerçekleştirilen Avrupa Çevrimiçi Çocukları projesi bulgularına göre çocukların \%53,3'ü sınıfta internet kullanımının okul kurallarında bahsedildiğini ve \%59,4'ü öğretmenleri tarafından interneti güvenli kullanmak için yollar önerildiğini bildirmişlerdir. Ayrıca yine bu araştırmada çocuklar, öğretmenlerinin bazı internet sayfalarının neden iyi ya da kötü olduğu hakkında bilgi verdiklerini (\%61), çevrimiçi kişilere nasıl davranmak gerektiğine dair yollar önerdiklerini (\%50) ve internette sıkıntı veren bir durumda nasıl davranılacağından bahsettiklerini (\%44) belirtmişlerdir (Kaşıkçı et.al., 2014).

Görüldüğü gibi yapılan araştırmalar göz önüne alındığında internet kullanıcılarının, bireylerin veya öğrencilerin interneti güvenli kullanma, bilişim güvenliğini sağlama, gelebilecek güvenlik tehditlerine karşı önlem alma konusunda bilgi düzeylerinin düşük olduğu anlaşılmaktadır (Dijle, 2006; Dijle \& Doğan 2011; Karaoğlan-Yılmaz et.al., 2014; Kaşıkçı et.al., 2014; Mert et.al., 2012; Shehri, 2012; Tekerek \& Mart, 2010; Tekerek \& Tekerek, 2013; Valcke et.al., 2007). Bunun yanında yapılan araştırmalarda, başta öğrencilere olmak üzere tüm bireylere bilgisayar ve internet güvenliğini sağlama konusunda bilgilendirici faaliyetlerin düzenlenmesinin gerekliliği üzerinde durulmaktadır (Canbek, 2007; Dijle \& Doğan, 2011; Emiral, 2004; İlbaş, 2009; Mart 2012; Mert et.al., 2010; NCSA, 2011; Öğütçü, 2010; Pruitt-Mentle \& Pusey, 2010; Pusey \& Sadera 2011; Rezgui \& Marks, 2008; Richardson, 2009; Tekerek \& Mart, 2010; Tekerek \& Tekerek; 2013; Ünver \& Canbay, 2010).

Mart (2012) küçük yaşlardan itibaren eğitim verilmesi, bilgi güvenliğinin zorunlu bir ders olarak okullarda yer alması, seminerler, internet siteleri ve kitle iletişim araçları ile bilgi güvenliği farkındalık bilincinin oluşturulması gerektiği önerilerinde bulunmuştur. Tekerek ve Tekerek (2013) öğrencilere, velilere ve öğretmenlere bilgi güvenliği farkındalıklarını artıracak eğitim faaliyetleri yürütülmesinin gerekli olduğunu belirtmiştir. Çocuklara evde, okulda ve sokakta nasıl güvenli yaşayacakları öğretildiği gibi bilgisayar ve internet ortamında da gelebilecek tehditlere karşı kendilerini nasıl koruyacaklarının öğretilmesi önemli görülmektedir. Amerika Birleşik Devletleri'nde öğretmenlerin, yöneticilerin ve teknoloji koordinatörlerinin tamamına yakını okullarda bilişim güvenliğinin öğretilmesi gerektiğini belirtmişlerdir (NCSA, 2011). Söz konusu araştırmada katııımcıların büyük çoğunluğu, biliş̧im güvenliğini sağlamaya yönelik verilmesi gereken eğitimlerin okullarda görev yapan teknoloji koordinatörleri tarafından verilmesi gerektiğini vurgulamışlardır.

Clinton (2009) bireylerin güvenliğini sağlayacak uygulamaya dönük, etkili ve davranış değişikliği yaratacak eğitim programlarının yer alması gerektiğini ve bu konuya yönelik yatıımların yapılması gerektiğini belirtmektedir. Ayrıca söz konusu araştırmada eğitimcilerin kendilerini bu konularda hazırlamalarının bir ihtiyaç olduğunu vurgulamaktadır. Benzer şekilde Pusey ve Sadera (2011) öğretmen adaylarının bilişim güvenliği bilgilerini ve bilişim güvenliği eğitimi verebilme yeterliliklerini artırmak için bilişim güvenliğinin, lisans programlarında yer alması gerektiği vurgulamaktadır. Dolayısıyla bu konuda özellikle okullarda görev yapacak olan BÖTE öğretmen adaylarına büyük görevler ve sorumluklar düşmektedir. Çelen ve ark. (2011) çocukların internette istenmedik durumlarda neler yapabilecekleri ile ilgili bilgilendirme çalışmaların en iyi okullarda ve Bilişim Teknolojileri ve Yazılım dersinde olacağını belirtmektedir. Ayrıca söz konusu araştırmada Çelen ve ark. (2011) Bilişim Teknolojileri ve Yazılım dersi içeriğinin bu tür bilgilendirici hususları ele alarak düzenlenmesi gerektiğini vurgulamaktadırlar. Yapılan araştırmalarda öğrencilerin bilişim güvenliği bilgilerinin ve farkındalıklarının yeterli düzeyde olmaması, bilişim güvenliğine yönelik eğitimlerin verilmesine vurgu yapılması ve bu araştırmada BÖTE öğretmen adaylarının bilişim güvenliği bilgilerinin yeterli düzeyde olmadığı sonucuna ulaşılması bu konuya yönelik eğitimlerin verilmesinin önemine ışık tutmaktadır.

Sonuç olarak bu araştırmada okullarda görev yapacak BÖTE öğretmen adaylarının bilişim güvenliğini sağlama ve gerekli önlemleri alma konularına yönelik bilgilerinin beklenen düzeyde olmadığı sonucuna ulaşılmıştır. BÖTE öğretmen adaylarının bilişim güvenliği bilgi sorularına verdikleri cevaplar göz önüne alındığında, adayların bilişim güvenliği bilgilerinin düşük seviyede olduğu görülmüştür. Ayrıca BÖTE öğretmen adaylarının e-posta güvenliği, vekil sunucunun görevi, reklam pencereleri (Pop-Up Ads), USB gibi depolama birimlerinin güvenli kullanımı, güvenlik duvarı gibi konularda bilgilerinin yeterli seviyede olmadığı tespit edilmiştir. Bunların yanında BÖTE öğretmen adaylarının bilişim güvenliği bilgilerinin günlük internet kullanım süresine, günlük bilgisayar kullanım süresine, bilgisayar sahip olma süresi gibi 
deneyimlere göre değişmemesi bilişim güvenliğinin sağlanmasının nitelikli bir eğitimle oluşabileceğini güçlendirmektedir. Dolayısıyla bu sonuçlardan, bilişim güvenliği konusunda eğitimlerin şart olduğu ve bilişim güvenliğine yönelik verilen eğitimlerin içerik, kapsam, süreç, farkındalık ve değerlendirme bakımından düzenlenmesinin gerekli olduğu anlaşılmaktadır. Bu sonuçlardan yola çıkarak, BÖTE öğretmen yetiştirme programında bilişim güvenliğine yönelik derslere yer verilmesinin yararlı olacağı düşünülmektedir. Bu dersin BÖTE bölümü için zorunlu, diğer öğretmen yetiştirme programları için ise seçmeli olarak programlarda yer almasının bilişim teknolojilerinin güvenli kullanımı açısından katkı sağlayacağı düşünülmektedir. Bunların yanında okullarda görev yapan Bilişim Teknolojileri rehber öğretmenlerinin öğrencilerinin bilgisayar ve internet güvenliğini sağlama konusunda ne tür faaliyetler içerisinde oldukları araştııılabilir. Bu araştırmanın sonuçları sadece çalışmaya katılan üniversiteler ve üçüncü, dördüncü sınıfta okuyan öğretmen adayları sınılı olmuştur. İleride yapılacak araştırmalarda kasıtlı örneklemler (bilişim güvenliği dersi olan veya olmayan programlar gibi) alınarak daha kapsamlı ve derinlemesine bilgi sağlayacak nitel araştırmaların yapılması önerilmektedir. Son olarak çalışmada kullanılan anketin var olan durumun daha iyi anlaşıması için hedef kitlesi farkıı başka araştırmalarda da kullanılması ve bu sonuçların karşılaştırılması faydalı olacaktır. 


\section{Introduction}

The use of Information Technology (IT) and internet rises day by day, and many benefits resulting from this technology are coming out. The daily emergence of new technologies possessing different features and functions is carrying forward the enlargement of the usage of these technologies. These technologies are required in many areas such as education, manufacturing, government and health services, trade, access to information, and the information-sharing, etc. (Çelik, 2007). These technologies holding many benefits as communication, problem solving, interaction with people, efficient use of time, correspondence, business facilitation, etc. is an indisputable reality of these technologies (Taş \& Kestellioğlu, 2011). In addition to rendering these benefits, information technology and internet usage are known to cause many security problems, as well. The problems of information security have been rising in parallel with the dramatic increase of computer and internet usage. The threats and cyber-attacks to IT have been increasing just as the usages of these technologies have been increasing.

The research conducted in recent years shows that the threats to especially IT have been intensified (Marinos, 2013; Symantec, 2013). As a result, many cybercrimes committed against individuals, the property rights of individuals, and various organizations have occurred. Checking the threats to IT security, it was concluded that releasing malware, phishing, denial of service, physical harm, spam and spyware are the most frequently performed attacks. (Canbek, 2005). As a result of these attacks and threats, physical and moral damages occur in individuals and institutions/organizations.

Presented in the literature, it was seen that there are initiatives for individuals to ensure their safety on internet. But the conducted researches show that individuals' information security knowledge is at a low lever (Dijle, 2006; Dijle \& Doğan 2011; Karaoğlan-Yılmaz, Yılmaz \& Sezer, 2014; Pusey \& Sadera, 2011; Shehri, 2012; Tekerek \& Mart, 2010; Tekerek \& Tekerek, 2013). The researches carried out on information security issues has focused on the necessity of making awareness-raising activities with the media and seminars, training from an early age and giving lectures at schools to ensure individuals' information security (Mart, 2012; Öğütçü, 2010).

Viewed from this perspective, trainings on providing IT security to the students starting from a very young age are inferred to be required. Thus, great tasks and responsibilities fall upon student teachers at the department of Computer Education and Instructional Technology (CEIT), who will serve at schools to ensure the students to take the necessary measures on IT. CEIT teachers can also give guidance to the other teachers in their schools. Based on the above statements, the purpose of this study is to determine CEIT student teachers' knowledge level on IT security and whether this knowledge alters according to several variables. The purpose of this study is to;

1) Examine the level of information security knowledge of CEIT student teachers

2) Examine whether CEIT student teachers' information security knowledge differs according to the
a) Age
b) Gender
c) Receiving training on IT security
d) Grade
e) Computer ownership period 
f) Daily computer usage time

g) Daily internet usage time

h) University

\section{Method}

\section{Research Design}

The study was carried out through the descriptive survey model which is one of the quantitative research methods. Descriptive survey model is known as a research model which determines participants' views, attitudes, and skills about a subject or event. The purpose of this research is to describe the situation in a general framework (Büyüköztürk, Kılıç Çakmak, Akgün, Karadeniz \& Demirel, 2012). Therefore, in this study we aimed to determine whether CEIT student teachers' knowledge of information security differs in terms of the various variables.

\section{Participants}

The participants are 375 third and fourth grade students receiving education at CEIT department from Sakarya, Amasya, Erzincan, and Siirt Universities. The study was conducted with the help of lecturers at these four universities where the lecturers work at. Considering the subject of research and available courses of CEIT undergraduate program, it was appropriate to add third grade student teachers to working groups for determining the qualifications provided by the program and whether the new program has a change in terms of education. The results obtained in this study is limited for these four universities. For determining the working group, ease of conducting the research is taken into account.

\section{Instrument}

As a data collection instrument, "Knowledge of Information Security" survey developed by Pusey \& Sadera (2011) was utilized. The survey consists of multiple-choice and demographic information security knowledge questions. The survey was adapted to Turkish by taking expert opinion. The survey contains important security issues including e-mail security, e-mail attachments, Proxy servers (Proxy Server), advertising windows (Pop-Up Ads), safe use of storage devices like USB memory, firewalls, creating a secure password. The experts have stated that the scope of the survey questions is appropriate and sufficient for measuring student teachers' information security knowledge. The survey has a valid structure based on the experts' opinions and it has also been published in an international journal. In the first part of the data collection tool, questions that determine CEIT student teachers' age, gender, class, daily computer and internet usage time, the owner of frequently used computer, and the duration of possessing a personal computer are existed. In the second part of the tool, there are seven multiple choice questions that measure student teachers' IT security information level. Pusey \& Sadera (2011) also included "I do not know" option to prevent guess of the student teachers in these questions and measure exactly what information they hold.

\section{Data Analysis}

The answers of CEIT student teachers to seven multiple-choice questions are delivered in percentage and frequency. In addition, the total score is calculated for seven multiple-choice questions that measure CEIT student teachers' IT security information. Examining the total scores of student teachers' information security knowledge, it was found that the data did not have a normal distribution. For that 
reason in analyzing the data, Mann-Whitney U-test for the two independent samples and Kruskal-Wallis $\mathrm{H}$-test for more than two independent samples were applied (Büyüköztürk, 2012). With the MannWhitney U-test, it was examined whether the total scores of student teachers' knowledge of information security show a significant difference according to the gender, class and receiving training on IT security. With the Kruskal-Wallis H-test, whether the total scores of student teachers' knowledge of information security show significant difference according to the age, computer ownership period, daily computer usage time, daily internet usage time and university was examined. In the analyzing the data, IBM SPSS Statistics 22 program was used and the level of significance was accepted as 05.

\section{Results}

As a result of this research, it was concluded that CEIT student teachers' information security knowledge was not at the expected level for providing information security and taking necessary measures against the threats. Considering CEIT student teachers' responses to the information security questions, it was observed that CEIT student teachers had a low level of information security knowledge. In addition, it was found that CEIT student teachers' knowledge is not adequate on some topics such as e-mail security, proxy server, advertising windows (Pop-Up Ads), safe use of storage devices and firewalls. CEIT student teachers' knowledge of IT security is determined to differ according to gender and university. Moreover, CEIT student teachers' information on IT security is concluded not to differ regarding age, years of computer ownership, class grade, duration of daily computer and internet usage, and whether any lesson or course on IT security was taken before.

\section{Discussion, Conclusion \& Implementation}

In the research conducted by Tekerek \& Tekerek (2013), it is concluded that the students' awareness of IT security is very low. In this research as well, students also state that they have insufficient knowledge of information security. Accordingly, Dijle \& Doğan (2011) also reach at the similar conclusion of individuals' not being aware of the cybercrimes subjects. In the research carried out by Valcke, Schellens, Van Keer \& Gerarts (2007) on elementary school students' use of safe Internet, it is determined that students have established a high level of unsafe Internet use.

Out of the research executed, it is understood that the internet users, individuals or students have possessed low level of awareness and knowledge of using the Internet safely, IT security, taking precautions against security threats (Dijle, 2006; Dijle \& Doğan, 2011; Mert, Bülbül \& Sağıroğlu, 2012; Shehri , 2012; Tekerek \& Mart, 2010; Tekerek \& Tekerek, 2013; Valcke et. al., 2007). In this study, it is reached that CEIT student teachers who will serve at schools do not seize the expected level of knowledge in ensuring information security and taking necessary precautions. In the United States (US), the research conducted by the National Cyber Security Alliance (NCSA) has determined that the teachers teach a few information security topics in the last 12 months (NCSA, 2011). Similarly Pruitt-Mantle \& Pusey (2010) in their survey, determining what the teachers' attitudes towards information security is, has concluded that few teachers teach basic internet skills. According to the results of that research, $25 \%$ of teachers teach password change, $14 \%$ of teachers teach use of anti-virus software, $12 \%$ of teachers teach information technology piracy, $16 \%$ of teachers teach firewall, 33\% of teachers teach dangers of social networks, $\% 39$ of teachers teach not the share information with strangers, $33 \%$ of teachers teach respect of privacy.

According to the results of European Online Children Project, which include 24 European countries, $53,3 \%$ of children have stated that the teachers have mentioned on rules of internet usage and $59,4 \%$ of children have stated that means to use the internet safely have been taught (Kaşıkçı et. al., 2014). Pusey \& Sadera (2011) emphasize on including information security lessons to undergraduate program for improving student teachers information security knowledge and improving their proficiency to teach information security. 
Therefore, out of these results, it is understood that the education about information security is essential and these information security instructions must be regulated in terms of content, process, awareness, and assessment. Based on that, it is considered to be useful to include a comprehensive course in CEIT department graduate program towards information security and Internet security and taking precautions against the attacks. Besides, the kind of activities that IT guiding teachers at schools are going through to ensure computer and internet safety can be investigated.

\section{Kaynakça}

Aydın, M. A. \& Sarısakal, M. N. (2003). E-ticaretin yeni yüzü mobil internet. Havacılık ve Uzay Teknolojileri Dergisi, 1(2), 83-90.

Bilgimi Koruyorum. (2011). Bilgi güvenliği - Hakkımızda. Retrieved December 11, 2013, from http://www.bilgimikoruyorum.org.tr/?bilgem-proje-hazirlayanlar-hakkinda.

Büyüköztürk, Ş. (2012). Sosyal bilimler için veri analizi el kitabı (17th ed.). Ankara: Pegem Akademi.

Büyüköztürk, Ş., Kılıç Çakmak, E., Akgün, Ö. E., Karadeniz, Ş. \& Demirel, F. (2012). Bilimsel araştırma yöntemleri (13th ed.). Ankara: Pegem Akademi.

Canbek, G. \& Sağıroğlu, Ş. (2007). Çocukların ve gençlerin bilgisayar ve internet güvenliği. Politeknik Dergisi, 10(1), 33-39.

Canbek, G. (2005). Klavye dinleme ve önleme sistemleri analiz, tasarım ve geliştirme. Unpublished master's thesis, Gazi Üniversitesi, Fen Bilimleri Enstitüsü, Ankara.

Clinton, L. (2009). Education's critical role in cybersecurity. EDUCAUSE Quarterly, 32(3), 60-61.

Çelen, F.K., Çelik, A. \& Seferoğlu, S.S. (2011). Çocukların internet kullanımları ve onları bekleyen çevrimiçi riskler. Akademik Bilişim Konferansı, 2-4 Şubat 2011, İnönü Üniversitesi, Malatya.

Çelik, L. (2007). Bilişim Teknolojileri. B. Güneş (Ed.), Bilgisayar-1 (5-24). Ankara: EDM Özel Eğitim Hizmetleri Yayıncılık.

Dedeoğlu, G. (2006). Bilişim toplumu ve etik sorunlar. Bursa: Alfa Aktüel Yayınları.

Dijle, H. (2006). Türkiye'de eğitimli insanların bilişim suçlarına yaklaşımı. Unpublished master's thesis, Gazi Üniversitesi, Fen Bilimleri Enstitüsü, Ankara

Dijle, H. \& Doğan, N. (2011). Türkiye'de bilişim suçlarına eğitimli insanların bakışı. Bilişim Teknolojileri Dergisi, 4(2), 43-53.

Emiral, F. (2004). Bilgi güvenliği bilincinin genele yayılması. Retrieved December 05, 2013, from http://www.denetimnet.net/UserFiles/Documents/50_45_1.pdf

Green, S. B. \& Salkind, N. J. (2008). Using SPSS for Windows and Macintosh: Analyzing and understanding data. Upper Saddle River: Pearson; Prentice Hall.

Güvenli ve Bilinçli İnternet Kullanım Projesi. (2013). Güvenli ve bilinçli internet kullanım projesi. $\begin{array}{llll}\text { Retrieved } & \text { December } & 25, & \text { from }\end{array}$ http://fethiye.meb.gov.tr/meb_iys_dosyalar/2013_02/18110143_gvenlvebInInternetkullanimprojesk tapik.pdf.

Internet World Stats. (2012). Europe internet usage stats facebook subscribers and population statistics. Retrieved March 25, 2014 from http://www.internetworldstats.com/stats4.htm.

ISTE. (2008). National educational standards for teachers. Redrieved December 23, 2013, from http://www.iste.org/docs/pdfs/nets-t-standards.pdf?sfvrsn=2 
Illbaş, Ç. (2009). Bilişim suçlarının sosyo-kültürel seviyelere göre algı analizi. Unpublished master's thesis, Başkent Üniversitesi, Fen Bilimler Enstitüsü, Ankara.

Karaoğlan-Yılmaz, G., Yılmaz, R. \& Sezer, B. (2014). Üniversite öğrencilerinin güvenli bilgi ve iletişim teknolojisi kullanım davranışları ve bilgi güvenliği eğitimine genel bir bakış. Bartın Üniversitesi Eğitim Fakültesi Dergisi, 3(1), 176-199.

Kaşıkçı, D.N., Çağıltay, K., Karakuş, T., Kurşun, A. \& Ogan, C. (2014). Türkiye ve Avrupa'daki çocukların internet alıskanlıkları ve güvenli internet kullanımı. Eğitim ve Bilim, 39(171), 230-243.

Kaçakcılık ve Organize Suçlar Daire Başkanlığı. (2011). Kaçakçıık ve organize suçlarla mücadele 2011 raporu. Ankara: KOM Yayınları.

Koç.net. (2005). Rizikometre-Türkiye İnternet Güvenliği Araştırma Sonuçları. İstanbul: KoçNet A.Ş.

Marinos, L. (2013). ENISA threat landscape 2013: Overview of current and emerging cyber-threats. Heraklion: European Union Agency for Network and Information Security Publishing. ISBN 978-9279-00077-5 doi:10.2788/14231.

Mart, i. (2012). Bilişim kültüründe bilgi güvenliği farkındalığı. Unpublished master's thesis, Kahramanmaraş Sütçü Imam Üniversitesi, Fen Bilimleri Enstitüsü, Kahramanmaraş.

Mert, M., Bülbül, H.i. \& Sağıroğlu, Ş. (2012). Milli eğitim bakanlığına bağlı okullarda güvenli internet kullanımı. Türk Bilim Araştırma Vakfı Bilim Dergisi, 5(4), 1-12.

Milli Eğitim Bakanlığı. (2008). Bilişim teknolojileri öğretmeni özel alan yeterlikleri. Retrieved May 06, 2013, from http://otmg.meb.gov.tr/alanbt.html.

National Cyber Security Alliance. (2011). The state of $k$-12 cyberethics, cybersafety and cybersecurity curriculum in the united states. National cyber security alliance microsoft corporation, Zogby/463.

Öğütçü, G. (2010). E-dönüşüm sürecinde kişisel bilişim güvenliği davranışı ve farkındalığın analizi. Başkent Üniversitesi, Fen Bilimleri Enstitüsü, Ankara.

Pruitt-Mentle, D. \& Pusey, P. (2010). State of k12 cyberethics, safety and security curriculum in U.S.: 2010 Educator opinion. Educational technology policy, Research and Outreach.

Pusey, P. \& Sadera, W. A. (2011). Cyberethics, cybersafety and cybersecurity: Preservice teacher knowledge, preparedness and the need for teacher education to make a difference. Journal of Digital Learning in Teacher Education, 28(2), 82-88.

Rezgui, Y. \& Marks, A. (2008). Information security awareness in higher education: A exploratory study. Computers \& Security, 27, 241-253. DOI:10.1016/j.cose.2008.07.008.

Richardson, R. (2009). CSI computer crime and security survey, Retrieved Februrary 24, 2014, from http://www.sis.pitt.edu/jjoshi/courses/IS2150/Fall11/CSIsurvey2008.pdf

Shehri, Y. (2012). Information security awareness and culture. British Journal of Arts and Social Sciences, 6(1), 611-69. ISSN: 2046-9578.

Siber Güvenlik Konferansı. (2014). Siber güvenlik konferansı 2014. Retrieved February 25, 2014, from http://www.siberguvenlikkonferansi.org

Symantec. (2013). Internet security threat report 2013. Retrieved November 24, 2013, from http://www.symantec.com/content/en/us/enterprise/other_resources/bistr_main_report_v18_201 2_21291018.en-us.pdf

Şahin, L., Çetin, B.I. \& Yıldırım, K. (2009). Bilişim teknolojilerindeki gelişmelerin işletmelerin strateji ve maliyet üzerine etkileri. Sosyal Siyaset Konferansları Dergisi, 56(1), 547-573. 
Ömer Faruk GÖKMEN ve Özcan Erkan AKGÜN - Çukurova Üniversitesi Eğitim Fakültesi Dergisi, 44(1), 2014, 61-84

Taş, i. E. \& Kestellioğlu, G. (2011). Halkla ilişkilerde internetin yeri ve önemi. Kahramanmaraş Sütçü Imam Üniversitesi Iktisadi ve Idari Bilimler Fakültesi Dergisi, 1(1), 73-92.

Tekerek, M. \& Mart, ì. (2010). K8 düzeyi için davranışsal bilgisayar ve internet güvenliği farkındalığı, 4.Uluslararası Bilgi Güvenliği ve Kriptoloji Konferansı Bildirileri. 6-8 Mayıs 2010, Orta Doğu Teknik Üniversitesi. Ankara.

Tekerek, M. \& Tekerek, A. (2013). A research on students' information security awareness. Turkish Journal of Education, 2(3), 61-70.

Telekomünikasyon İletişim Başkanlığı İnternet i̇hbar Merkezi. (2010). Retrieved December 13, 2013, from http://ihbarweb.org.tr/index.html

Türkiye Bilişim Şurası. (2002). E-devlet çalışma grubu raporu. Retrieved December 06, 2013, from http://www.tbd.org.tr/usr_img/cd/kamubib12/diger/SuraRaporu.DOC

Türkiye İstatistik Kurumu. (2013). Bilgi toplumu istatistikleri. Retrieved November 26, 2013, from http://www.tuik.gov.tr/UstMenu.do?metod=temelist

Ulusal Bilgi Güvenliği Kapısı. (2014). Ulusal bilgi güvenliği kapısı hakkında. Retrieved December 11, 2013, from https://www.bilgiguvenligi.gov.tr/hakkimizda.html

Ünver, M. \& Canbay, C. (2010). Ulusal ve uluslararası boyutlarıyla siber güvenlik. Elektrik Mühendisliği Dergisi, 438, 94-103.

Valcke, M., Schellens, T., Van Keer, H. \& Gerarts, M. (2007). Primary school children's safe and unsafe use of the internet at home and at school: An exploratory study. Computers in Human Behavior, 23, 2838-2850. 
